\title{
ASYMPTOMATIC INFECTIONS BY DIARRHEAGENIC Escherichia coli IN CHILDREN FROM MISIONES, ARGENTINA, DURING THE FIRST TWENTY MONTHS OF THEIR LIVES
}

\author{
Marina QUIROGA(1), Patricia OVIEDO(1), Isabel CHINEN(2), Eduardo PEGELS(1), Elizabeth HUSULAK(1), Norma BINZTEIN(2), Marta RIVAS(2), \\ Lydia SCHIAVONI(3) \& Marta VERGARA(1)
}

\begin{abstract}
SUMMARY
Diarrheagenics Escherichia coli are the major agents involved in diarrheal disease in developing countries. The aim of this study was to evaluate the time of appearance of the first asymptomatic infection by the different categories of diarrheagenic E. coli in 44 children since their birth and during the first 20 months of their lives. In all of the children studied, we detected at least one category of diarrheagenic $E$. coli through the 20 months of the study. 510 diarrheagenic E. coli (33.5\%) were obtained from the 1,524 samples collected from the 44 children during the time of the study (31.4\% EAggEC, 28.8\% EPEC, 27.1\% DAEC, and 12.7\% ETEC). Neither EHEC nor EIEC were identified. The median age for diarrheagenic E. coli colonization was 7.5 months. The mean weaning period was 12.8 months and the mean age for introduction of mixed feeding (breast fed supplemented) was 3.8 months. A significantly lower incidence of diarrheal disease and asymptomatic infections was recorded among the exclusively breast-fed rather than in the supplemented and non breast-fed infants. For ETEC, EPEC and EAggEC the introduction of weaning foods and complete termination of breast-feeding were associated with an increase of asymptomatic infections.
\end{abstract}

KEYWORDS: Children; Asymptomatic infections; Diarrheagenic Escherichia coli; Breast-feeding.

\section{INTRODUCTION}

Diarrhea constitutes the most common cause of morbidity and mortality among infants and children in developing countries. In 1994, the incidence rate of diarrhea in Argentina was 1,594.70/100,000 inhabitants, and in Misiones, a province situated in the northeastern of Argentina, it was 3,740.50/100,000 inhabitants ${ }^{2}$, a rate that doubled the national mean one that same year. Diarrhea constitutes a severe health problem in Misiones, especially for children, since most of the people do not yet have access to piped water and adequate sanitary facilities.

Diarrheagenics E. coli, the major agents involved in diarrheal disease in developing countries, are classified into six categories as enteropathogenic E. coli (EPEC); enterotoxigenic E. coli (ETEC); enterohemorrhagic E.coli (EHEC); enteroinvasive E. coli (EIEC); enteroaggregative E.coli (EAggEC) and diffuse adherent E.coli (DAEC); according to differences in their pathogenicity mechanisms, their interaction with the intestinal mucosa, diarrheic syndromes and epidemiological characteristics ${ }^{21,31}$.

In previous reports ${ }^{37,38,39}$, we informed the detection of E. coli as the most frequent microbial agent involved in symptomatic and asymptomatic infections in Misiones children. In different cohorts studies during 10 years (1986-1996), we had recorded a high number of asymptomatic infections by E.coli, especially ETEC (18.9\%, unpublished data).
The aim of this study was to evaluate the time of appearance of the first asymptomatic infection by the different categories of diarrheagenic $E$. coli and the risk factors associated to them in 44 children followed from their birth to 20 months of age.

\section{MATERIALS AND METHODS}

Area of study: Misiones is a province situated in the Northeastern of Argentina. It has a warm subtropical climate. The median annual temperature is about $20^{\circ} \mathrm{C}$, ranging from $-2{ }^{\circ} \mathrm{C}$ to $40{ }^{\circ} \mathrm{C}$.

Misiones is one of the wettest areas in the country. The intense yearly rainfall reaches about 1,600 to $1,900 \mathrm{~mm}$. There are important rivers, brooks and waterways in the area, which reach a total number of more than 600 .

Study population: A total of 44 children from 44 households were followed from birth to 20 months of age, with weekly visits to document the presence of diarrhea or other illness. The infants were selected after informed consent from their mothers.

Exclusion criteria for inclusion of pregnant women were: serological HIV positive and reactive syphilis. Identical criteria was adopted for the newly borns, plus a more than 24 hour stay at the hospital.

(1) National University of Misiones, Av. Mariano Moreno 1375, (3300) Posadas, Misiones, Argentina.

(2) National Institute of Infectious Diseases. ANLIS- “Dr. Carlos G. Malbrán”, Velez Sarsfield 563, (1281) Buenos Aires, Argentina.

(3) National University of Misiones, Tucumán 1946, (3300) Posadas, Misiones, Argentina.

Correspondence to: Dr. Marta Vergara, National University of Misiones, Av. Mariano Moreno 1375, (3300) Posadas, Misiones, Argentina. FAX: 0054-3752-435118. 


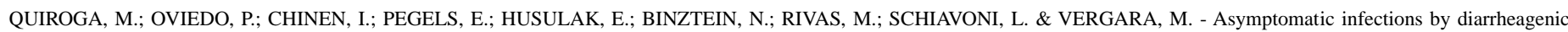
Escherichia coli in children from Misiones, Argentina, during the first twenty months of their lives. Rev. Inst. Med. trop. S. Paulo, 42 (1): 9-15, 2000.

Socioeconomic situation: All the study subjects lived in an area about $20 \mathrm{~km}$ off the Central Hospital. The evaluation of their socioeconomic status was done on the basis of the information supplied by their mothers. The average number of members per family was 4.65 .

The socioeconomic situation of the families was analyzed so as to know the chance children had of counting with the necessary basic needs.

The relationship between consumers and working members of the family group was taken as an indicator.

An index was elaborated for giving a score to house construction quality. It consisted of a simple sum of points given this way: more points to more expensive and longer lasting building materials.

Another simple variable was elaborated to analyze sanitary conditions as a whole in households. It was a simple sum which combined water treatment (intradomiciliary piped water, public tap, well or water from an excavation or brook), refuse treatment (collection, burning or open air disposal) and toilets for refuse disposal (indoor flush toilet, pit toilet or no toilet).

Samples: Fecal samples were collected every fifteen days from healthy children, and every time the child had diarrhea, after spontaneous evacuation, and stool samples were placed in Cary-Blair transport medium and taken to the laboratory for immediate test.

Bacteriological analysis: Fecal samples were analyzed for the presence of common diarrheal pathogens according to methods suggested by the Enteric Infections Manual of the World Health Organization $(\mathrm{WHO})^{27}$.

The identification of $E$. coli strains was done testing 5 lactosefermenting colonies. Colonies were biochemically characterized by standard methods ${ }^{15}$.

Heat-labile enterotoxin (LT) of ETEC was assayed by immunoenzyme assays (GM1-ELISA) and heat-stable enterotoxin (ST) by competitive inhibition GM1-ELISA. Monoclonal antibodies kindly supplied by A-M. Svennerholm (University of Göteborg, Sweden), were used in both cases ${ }^{33,34}$.

Non ETEC isolates were sent to the Instituto Nacional de Enfermedades Infecciosas ANLIS- "Dr. Carlos G. Malbrán" for identification of EIEC, EPEC, DAEC, EAggEC and EHEC.

EIEC detection was carried out on lactose non-fermenting colonies or slow lactose-fermenting colonies, by direct ELISA against outer membrane protein $(\mathrm{OMP})^{7}$ and keratoconjunctivitis test in the conjunctival bag of the Guinea pig $^{32}$.

The search for EPEC ${ }^{13,18,23,24}$, DAEC 5 , EAggEC ${ }^{3}$ and $\mathrm{EHEC}^{26}$ was carried out by colony blot hybridization with specific probes. Recombinant plasmids were kindly provided by J. Kaper and J. Nataro, Center for Vaccine Development, Baltimore, Md, U.S.A.

The DNA probes used for the detection of diarrheagenic E.coli are shown in Table 1 .

An E. coli strain was considered as belonging to the EPEC category when eae or eae/bfp were detected by colony blot hybridization.

Statistical analysis: It was carried out according to the method for the analysis of hypothesis of existence of statistic significant differences among proportions with a $5 \%$ significance ${ }^{11}$.

\section{RESULTS}

In the present study diarrheagenic $E$. coli categories were detected in all the children during the 20 months study. Although 97 diarrheal episodes (2.2 episodes/infant/20 months) were recorded, the present results refer only to asymptomatic diarrheagenic $E$. coli infections.

A total of 510 E. coli strains (33.5\%) were detected in the 1524 samples collected from the 44 children: $31.4 \%$ EAggEC, $28.8 \%$ EPEC, $27.1 \%$ DAEC, and $12.7 \%$ ETEC (70.8\% LT, $20 \%$ ST and $9.2 \%$ LT/ST). Neither EHEC nor EIEC were identified.

Table 1

DNA probes used for the detection of diarrheagenic E. coli

\begin{tabular}{|c|c|c|c|}
\hline E. coli category & Detected virulence factor & Recombinant plasmid & Probe obtained with restriction enzyme \\
\hline \multirow[t]{2}{*}{ EPEC } & $e^{a} e^{a}$ & pCVD434 & $1-\mathrm{kb} / \mathrm{Sal} \mathrm{I}-K p n \mathrm{I}$ \\
\hline & $\mathrm{bfp}^{\mathrm{b}}$ & pMSD207 & 852-bp / Eco RI \\
\hline EAggEC & $\mathrm{AA}^{\mathrm{c}}$ & pCVD432 & 700-bp / Pst I-Eco RI \\
\hline DAEC & $\mathrm{DA}^{\mathrm{d}}$ & pSLM852 & 390-bp / Pst I \\
\hline \multirow[t]{3}{*}{ EHEC } & EHEC-fimbrial & pCVD419 & 3.4-kb / Hind III \\
\hline & Stx $1^{\mathrm{e}}$ & pJN37-19 & 1.1-kb / BamHI \\
\hline & Stx $2^{\mathrm{f}}$ & pNN110-18 & 842-bp / SmaI-Pst I \\
\hline
\end{tabular}

aattaching and effacing factor, benteroadherence factor, ${ }^{\mathrm{c}}$ aggregative adherence, ${ }^{\mathrm{d}}$ diffuse adherence, ${ }^{\mathrm{e}}$ Shiga-like toxin 1 , ${ }^{\mathrm{f}}$ Shiga-like toxin 2 


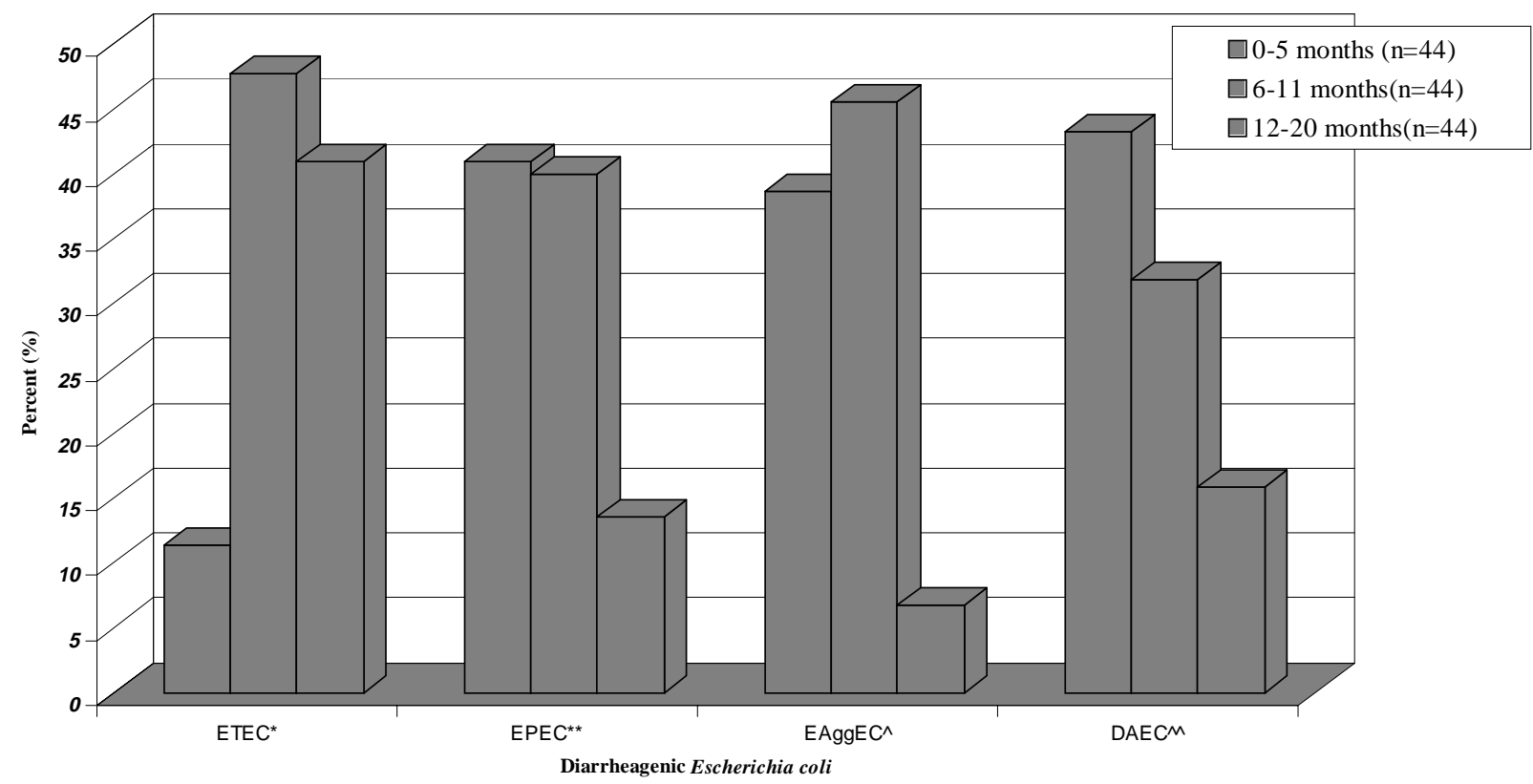

*Enterotoxigenic Escherichia coli ${ }^{* *}$ Enteropathogenic Escherichia coli $\wedge^{\wedge}$ Enteroaggregative Escherichia coli ${ }^{\wedge}$ Diffuse adherent Escherichia coli

Fig. 1 - Age distribution of diarrheagenic Escherichia coli isolated from the 44 studied children through the 20 months of the study

Table 2

First symptomatic and asymptomatic infections by feeding regimen in 44 studied children

\begin{tabular}{|c|c|c|c|c|c|c|}
\hline & \multicolumn{4}{|c|}{ Breast-fed } & & \\
\hline & \multicolumn{2}{|c|}{ exclusively $(n=42)^{*}$} & \multicolumn{2}{|c|}{ Supplemented $(\mathrm{n}=44)$} & \multicolumn{2}{|c|}{ Non breast-fed $* *$} \\
\hline & No. & $\%$ & No. & $\%$ & No. & $\%$ \\
\hline First symptomatic infection & 2 & 4.8 & 22 & 50.0 & 24 & 64.9 \\
\hline First asymptomatic infection & 16 & 38.1 & 38 & 86.4 & 21 & 56.8 \\
\hline
\end{tabular}

*two children never had exclusively breast-fed

** when the study was finished, seven children continued with supplemented breast-fed

There were no significant differences among the detection of EAggEC, EPEC and DAEC ( $p>0.05)$. However, there were significant differences between these three categories (EAggEC, EPEC and DAEC) and ETEC $(\mathrm{p}<0.05)$.

Mixed infections were found in 43 out of 1524 (2.8\%) fecal samples studied, especially in those cases with DAEC infections (23.3\% EPECDAEC and 20.9\% EAggEC-DAEC).

Ninety-six of the 160 EAggEC (60\%), 88 of the 147 EPEC (60\%) and 46 of the 65 ETEC ( $71 \%$ ) were more frequently detected during the Spring and Summer seasons $(\mathrm{p}<0.05)$, whereas 83 of the 138 DAEC $(60 \%)$ was more frequently identified in Autumn-Winter $(\mathrm{p}<0.05)$.

The median age for diarrheagenic $E$. coli colonization was 7.5 months (6.7 months, 6.6 months, 6.9 months, and 9.7 months for EAggEC, DAEC, EPEC and ETEC, respectively).
Figure 1 shows the age distribution of diarrheagenic E. coli isolated from 44 children through the 20 months of the study.

ETEC was identified more frequently $(\mathrm{p}<0.05)$ in infants more than 6 months of age. EPEC, EAggEC and DAEC were more frequently identified $(\mathrm{p}<0.05)$ in infants less than 1 year old.

The mean weaning period was 12.8 months and the mean age for introduction of mixed feeding (breast fed supplemented) was 3.8 months.

Table 2 shows the percentage of symptomatic infections vs. asymptomatic ones recorded in the exclusively breast-fed, breast-fed supplemented and non breast-fed populations.

A significantly lower incidence of diarrheal disease and asymptomatic infections was recorded among the exclusively breast-fed than in the supplemented and non breast-fed infants $(\mathrm{p}<0.05)$. 


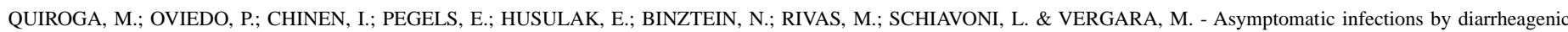
Escherichia coli in children from Misiones, Argentina, during the first twenty months of their lives. Rev. Inst. Med. trop. S. Paulo, 42 (1): 9-15, 2000.

Table 3

First asymptomatic infection by diarrheagenic Escherichia coli in relation to the feeding regime in 44 studied children

\begin{tabular}{|c|c|c|c|c|c|c|c|c|}
\hline & \multicolumn{2}{|c|}{ ETEC* $*$} & \multicolumn{2}{|c|}{ EPEC $* *$} & \multicolumn{2}{|c|}{$\mathrm{EAggEC}^{\wedge}$} & \multicolumn{2}{|c|}{ DAEC $^{\wedge \wedge}$} \\
\hline & No. & $\%$ & No. & $\%$ & No. & $\%$ & No. & $\%$ \\
\hline Breast-fed exclusively $(n=42) \#$ & 3 & 7.1 & 8 & 19.0 & 8 & 19.0 & 10 & 23.8 \\
\hline Breast-fed supplemented $(n=44)$ & 17 & 38.6 & 25 & 56.8 & 25 & 56.8 & 20 & 45.5 \\
\hline Non breast-fed (n=37)\#\# & 17 & 45.9 & 8 & 21.6 & 9 & 24.3 & 9 & 24.3 \\
\hline Total & 37 & & 41 & & 42 & & 39 & \\
\hline
\end{tabular}

*Enterotoxigenic Escherichia coli; $* *$ Enteropathogenic Escherichia coli; ${ }^{\wedge}$ Enteroaggregative Escherichia coli; ${ }^{\wedge}{ }^{\wedge}$ Diffuse adherent Escherichia coli; \#two children never had exclusively breast-fed; \#\# when the study was finished, seven children continued with supplemented breast-fed

The first asymptomatic infection appeared at the time of the implementation of mixed feeding: $45.5 \%$ of cases by DAEC, $56.8 \%$ of cases by EAggEC and by EPEC, and $38.6 \%$ of cases by ETEC (Table $3)$.

For ETEC, EPEC and EAggEC the introduction of weaning foods and complete termination of breast-feeding were associated with an increase of asymptomatic infections $(\mathrm{p}<0.05)$.

\section{DISCUSSION}

An important factor in the genesis of diarrhea sequel as deficits of height and weight in children of less developed countries, is the widespread microbiological contamination of the environment, which among other factors, is responsible for repeated infections ${ }^{1}$.

Previous studies carried out by BRUNSER et al. ${ }^{6}$ showed that adequate hygienic practices and good sanitary conditions may lower significantly the prevalent levels of contamination.

The analysis of the different socioeconomic variables of the families showed that they presented a certain homogeneity, with a satisfactory life level that allowed them to make an optimum use of available resources. That is why the children population studied was considered to be a group that presented good sanitary care. In spite of this, $100 \%$ of these children presented asymptomatic infections by diarrheagenic $E$. coli through the 20 months of the study.

We found that EAggEC (31.4\%) was the category most frequently identified in asymptomatic infections. Our data are comparable to the study carried out by FANG et al. ${ }^{16}$, who identified a high percentage of asymptomatic infections by EAggEC in Brazilian children (15-31\%). This high rate of EAggEC identification in children without diarrhea increases still more the controversy about the meaning of these strains in diarrhea etiology $\mathrm{y}^{20}$.

In underdeveloped countries, EPEC organisms are considered a major cause of endemic infantile diarrhea ${ }^{21}$, but ROWLAND et al. ${ }^{30}$ in Gambia found that $42.6 \%$ of asymptomatic infants excreted EPEC. Excretion of EPEC by asymptomatic infants found by us $(28.8 \%)$ is similar to those reported by FIGUEROA et al. in Chile $(20 \%)^{17}$.

The high rate of DAEC identification in asymptomatic children observed, corroborates the findings presented in other reports ${ }^{9,14,19,25}$ where a lack of an association between DAEC and diarrhea was found.

Mixed asymptomatic infections were relatively uncommon. DAEC was the category most frequently involved in these multiple infections.

Only DAEC strains were isolated in our study more significantly during Autumn and Winter. Even when this fact has to be considered, in a sub-tropical area like ours, without marked seasonal differences, enteropathogenic agents are isolated all the year round ${ }^{38}$.

In a previous study (unpublished data), we found a high number of asymptomatic infections by ETEC. Eighty-three percent of both toxins (LT, ST) producing ETEC were found in asymptomatic children older than 2 years, which suggests that previous exposure to these strains made them develop a natural immunity to these infections.

In the present study, ETEC was detected in $12.7 \%$ of the asymptomatic children and was more frequently identified in infants of the age group 6-11 months (Figure 1). EPEC, EAggEC and DAEC were more frequently detected in asymptomatic infants less than oneyear-old $(p<0.05)$ and in contrast to ETEC, the frequency of asymptomatic infections of EPEC, EAggEC and DAEC tended to decrease with age.

This situation has been previously described ${ }^{8}$ for EPEC. The reason for the decrease with age is unknown, but possible explanations include acquisition of immunity or loss of specific receptors in the gut mucosa with increasing age ${ }^{35}$.

The incidence of asymptomatic infections by ETEC, as has already been demonstrated ${ }^{8}$, starts at birth and increases with age; however, the incidence of diarrhea is very low during the first year of life, due to the transference of specific antibodies present in maternal milk.

We were able to demonstrate this when evaluating the behavior of sera antibodies in Misiones children ${ }^{28}$. In the aforementioned work we concluded that the early and repeated contact with people in an endemic area like ours allowed them to obtain a quick immunological response to an even small antigenic stimulus, and that this would take them to reach a self-control of the disease, explaining in this way the fact that older people are not attacked by an ETEC diarrhea illness as severely as other people from non endemic areas. 
The mean incidence of diarrhea was not high in our study population, possibly due to the factors analyzed before for ETEC, because children were visited by the social worker once a week, meaning this that a greater care of them was taken, what coincides with what BHAN et al. ${ }^{4}$ have reported.

In a previous study ${ }^{38}$, where several risks associated with infantile diarrhea were analyzed, we found that people with fewer cultural resources used contaminated water for hygienic practices, consumption and recreation, in spite of having potable water.

In view of our present study with high and early appearance of asymptomatic infections by diarrheagenic $E$. coli in children from families of a good socioeconomic status in general, the earlier experience mentioned $^{38}$ made us think of the presence of high colonization rates.

Our data (Table 2) show that the incidence of diarrheal disease and asymptomatic infections were significantly lower among the exclusively breast-fed infants, and that the first asymptomatic infection by all the categories of diarrheagenic E. coli appeared, in a significantly percentage, at the time of the implementation of mixed feeding (Table 3).

We agree with ARAYA et al. ${ }^{1}$ that a possible explanation to our findings is that infants were in contact with low infective doses and that they were "protected" by the best hygienic practices at their homes, what might allow the presence of asymptomatic infections.

Our data stress that the implementation of mixed feeding is associated to risks in a highly contaminated environment like ours, despite the cares and good socioeconomic status of the sample children. Previous studies indicate that the substitution of bottle-feeding for breast-feeding enhances the risk of contracting diarrhea ${ }^{29,36}$.

A high incidence of asymptomatic infections was found among breast-fed infants. These data suggest that while breast milk protects against episodes of diarrhea, it does not hinder the transit of pathogenic bacteria along the gastrointestinal tract ${ }^{17}$.

We believe that even when the newborns were exposed to enteric pathogens harbored by their mothers, anti-infectious factors present in colostrum and maternal milk permitted these infections to be transient and asymptomatic, a fact that has already been documented by MATA ${ }^{22}$.

Due to its potential as health promoter, breast-feeding acquires a particular importance in diarrhea prevention. This is particularly important in poor countries where the contaminated environment offers so many opportunities for intestinal infections. This is observed when mixed feeding is introduced, a fact that does not entail an impact of infections in a non-contaminated setting.

Several studies have demonstrated that breast-feeding ensures a protection against diarrhea in children ${ }^{10,12}$. IgA and oligosaccharides present in maternal milk are able to inhibit EPEC in vitro adhesion, for example, being the most important protecting elements during the first weeks of lactancy.

No matter the fact these children belong to families with satisfied basic needs, apparently certain hygienic habits practiced during and after their lactancy, allowed the incorporation of enteric pathogens very early in their lives. This shows the need for the implementation of certain sanitary education measures.

The most important issue in diarrheic illness is related to its control and prevention. The history of industrialized countries shows that control and prevention of diarrhea rest on an improvement of natural environment ${ }^{22}$.

The present study emphasizes that breast-feeding is of great value in the struggle against diarrhea, so it is necessary to make efforts to avoid the trends toward early weaning.

This is particularly important in less-developed countries, like ours, where the environment provides ample opportunities for continuous children's intestinal infections.

\section{RESUMO}

\section{Infecções assintomáticas por Escherichia coli causadoras de diarréias em crianças de Misiones, Argentina durante os primeiros vinte meses de vida}

E. coli é o principal agente envolvido na produção de diarréias nos países em desenvolvimento. O objetivo deste estudo foi avaliar o tempo de aparição da primeira infecção assintomática pelas diferentes categorias de $E$. coli causadoras de diarréias em 44 crianças desde o nascimento e durante os primeiros 20 meses de vida. Em todas as crianças estudadas foram detectadas algumas categorias de $E$. coli causadoras de diarréia ao longo dos 20 meses do estudo. Durante o estudo foram obtidas 510 E. coli causadoras de diarréia $(33,5 \%)$ a partir das 1524 amostras colectadas das 44 crianças (31,4\% EAggEC, 28,8\% EPEC, 27,1\%DAEC e 12,7\% ETEC). Não foram detectadas nem EHEC e nem EIEC. A idade média para a colonização pelas $E$. coli produtoras de diarréia foi de 7,5 meses. O período médio até o desmame foi de 12,8 meses e a idade média para a introdução de alimentação mista foi de 3,8 meses. Uma incidência significativamente baixa de diarréia e infecções assintomáticas foi registrada na época de amamentação exclusiva em relação às crianças com alimentação mista e àquelas que já não mamavam. Para ETEC, EPEC e EAggEC, a introdução de alimentos ao desmame e ao final da amamentação estiveram associadas com um aumento das infecções assintomáticas.

\section{ACKNOWLEDGEMENTS}

The authors thank the students Liliana Lubacsewski, Hugo Macaya and Angel Luis Derluk for their assistance at the laboratory, Drs. Gladys Wagner, Silvia Camacho, Ana Castelnovo and Ana Castex for their obstetrician assistance to the pregnant women; Drs. Rosa Zambiasso and Tita Berazategui for the neonatal assistance of the babies and Drs. Liliana Arce and María Ester Pianessi for their pediatric assistance. We also acknowledge the technical assistance of German Chillemi and Ana Garbini. Authors wish to thank Prof. Cristina Mayol and Dr. Alberto Fenocchio for their technical assistant on the manuscript.

This work was supported by the Swedish Agency for Research Cooperation with Developing Countries (SAREC). 
QUIROGA, M.; OVIEDO, P.; CHINEN, I.; PEGELS, E.; HUSULAK, E.; BINZTEIN, N.; RIVAS, M.; SCHIAVONI, L. \& VERGARA, M. - Asymptomatic infections by diarrheagenic Escherichia coli in children from Misiones, Argentina, during the first twenty months of their lives. Rev. Inst. Med. trop. S. Paulo, 42 (1): 9-15, 2000.

\section{REFERENCES}

1. ARAYA, M.; FIGUEROA, G.; ESPINOZA, J.; ZANUR, X. \& BRUNSER, O. - Acute diarrhoea and asymptomatic infection in Chilean preschoolers of low and high socioeconomic strata. Acta paediat. scand., 75: 645-651,1986.

2. ARGENTINEAN Health Ministry. Infantile and Maternal Nutrition Program. Social Indicators. Province of Misiones, 1995.

3. BAUDRY, B.; SAVARINO, S.J.; VIAL, P.; KAPER, J.B. \& LEVINE, M.M. - A sensitive and specific DNA probe to identify enteroaggregative Escherichia coli, a recently discovered diarrheal pathogen. J. infect. Dis., 161: 1249-1251, 1990.

4. BHAN, M.K.; RAJ, P.; LEVINE, M.M. et al. - Enteroaggregative Escherichia coli associated with persistent diarrhoea in a cohort of rural children in India. J. infect. Dis., 159: 1061-1064, 1989.

5. BILGE, S.S.; CLAUSEN, C.R.; WAYNE L. \& MOSELEY, S.L. - Molecular characterization of a fimbrial adhesin, F1845, mediating difuse adherence of diarrheaassociated Escherichia coli to HEp-2 cells. J. Bact., 26: 1292-1297, 1988.

6. BRUNSER, O.; FIGUEROA, G.; ARAYA, M.; ESPINOZA, J. \& BRUNSER, O. Infectious and diarrheal disease. In: WHITE, P.L. \& SELVEY, N., ed. Malnutrition: determinants and consequences. Current Topics on Nutrition and Disease. New York, Alan R. Liss, 1984. v. 10, p. 259-270.

7. CHINEN, I.; RIVAS, M.; CAFFER, M.I.; CINTO, R.O. \& BINSZTEIN, N. - Diagnóstico de Escherichia coli enteroinvasiva asociada a diarrea. Rev. argent. Microbiol., 25: 27-35, 1993.

8. CRAVIOTO, A.; REYES, R.E.; TRUJILLO, F. et al. - Risk of diarrhoea during the first year of life associated with initial and subsequent colonization by specific enteropathogens. Amer. J. Epidem., 131: 886-904, 1990.

9. CRAVIOTO, A.; TEllO, A.; NAVARRO, A. et al. - Association of Escherichia coli HEp-2 adherence pattern with type and duration of diarrhoea. Lancet, 337: 262264, 1991.

10. CRAVIOTO, S.; TELLO, A.; VILLAFÁN, H. et al. - Inhibition of localized adhesion of enteropathogenic Escherichia coli to HEp-2 cells by immunoglobulin and oligosaccharide fractions of human colostrum and breast milk. J. infect. Dis., 163: 1247-1255, 1991

11. DANIEL, W. - Estimación de los parámetros de la población. In: DANIEL, W. Estadística con aplicación a las ciencias sociales y a la educación. Bogotá, McGraw-Hill Latinoamericana, 1981. p. 141-187.

12. DELNERI, M.T.; CARBONARE, S.B.; SILVA, M.L.; PALMEIRA, P. \& CARNEIROSAMPAIO, M.M. - Inhibition of enteropathogenic Escherichia coli adhesion to HEp2 cells by colostrum and milk from mothers delivering low-birth-weight neonates. Europ. J. Pediat., 156: 493-498, 1997.

13. DONNENBERG, M.S. \& KAPER, J.B. - Enteropathogenic Escherichia coli. Infect. Immun., 60: 3953-3961, 1992.

14. ECHEVERRÍA, P.; SERICHANTALERG, O.; CHANGCHWALIT, S. et al. - Tissue culture-adherent Escherichia coli in infantile diarrhoea. J. infect. Dis., 165: 141$143,1992$.

15. EDWARDS, P.R. \& EDWING, W.H. - The genus Escherichia. In: EDWARDS, P.R. \& EDWING, W.H., ed. Identification of Enterobacteriaceae. 3.ed. Minneapolis, Burgess, 1972. p. 67-107.

16. FANG, G.D.; LIMA, A.A.; MARTINS, C.V.; NATARO, J.P. \& GUERRANT, R.L. Etiology and epidemiology of persistent diarrhea in northeastern Brazil: a hospitalbased prospective case-control study. J. pediat. Gastroent. Nutr., 21: 137-144, 1995.

17. FIGUEROA, G.; TRONCOSO, M.; ARAYA, M.; ESPINOZA, J. \& BRUNSER, O. Enteropathogen carriage by healthy individuals living in an area with poor sanitation. J. Hyg. (Lond.), 91: 499-507, 1983.
18. GIRON, J.A.; SUC YUE HO, A. \& SCHOOLNIK, G.K. - An inducible bundle-forming pilus of enteropathogenic Escherichia coli. Science, 254: 710-713, 1991.

19. GOMES, T.A.; BLAKE, P.A. \& TRABULSI, L.R. - Prevalence of Escherichia coli strains with localized, diffuse, and aggregative adherence to HeLa cells in infants with diarrhoea and matched controls. J. clin. Microbiol., 27: 266-269, 1989.

20. GONZÁLEZ, R.; DÍAZ, C.; MARIÑO, M. et al. - Age-specific prevalence of Escherichia coli with localized and aggregative adherence in Venezuelan infants with acute diarrhoea. J. clin. Microbiol., 35: 1103-1107, 1997.

21. LAW, D. - Adhesion and its role in the virulence of enteropathogenic Escherichia coli. Clin. Microbiol. Rev., 7: 152-173, 1994

22. MATA, L. - Epidemiology of acute diarrhoea in chilhood. An overview. In: BELATTI, J.A., ed. Acute diarrhoea: its nutritional consequences in children. New York, Raven Press, 1983. p. 3-22.

23. NATARO, J.P. - Molecular diagnosis of EPEC. Rev. Microbiol. (S. Paulo), 27 (suppl. 1): $54-57,1996$.

24. NATARO, J.P.; BALDINI, M.M.; KAPER J.B. et al. - Detection of an adherence factor of enteropathogenic Escherichia coli with a DNA probe. J. infect. Dis., 152: 560565,1985 .

25. NATARO, J.P. \& LEVINE, M.M. - Bacterial diarrheas. In: KAPIKIAN, A.P., ed. Viral infections of the gastroientestinal tract. 2.ed. New York, Marcel Dekker, 1994. p. $697-752$.

26. NEWLAND, J.W. \& NEIL, R.J. - DNA probes for Shiga-like toxins I and II and for toxin-converting bacteriophages. J. clin. Microbiol., 26: 1292-1297, 1988.

27. ORGANIZACIÓN PANAMERICANA DE LA SALUD. Oficina Regional de la Organización Mundial de la Salud - Manual de laboratorio de infecciones entéricas agudas. Análisis primario de muestras fecales. Washington, OPAS, 1983.

28. RIVAS, M.; BINSZTEIN, N.; BASANTA, G. et al. - Antibody responses against Escherichia coli heat-labile toxin and colonization factor antigens I and II in Argentinian children. J. infect. Dis., 171: 1045-1049, 1995.

29. ROWE, B. - The role of Escherichia coli in gastroenteritis. Clin. Gastroent., 8: 625$644,1979$.

30. ROWLAND, M.G.M.; COLE, T.J.; TULLY, M.; DOLBY, J.M. \& HONOUR, P. Bacteriostasis of Escherichia coli in endemic diarrheal disease. J. infect. Dis., 137: 292-297, 1980.

31. SEARS, C. \& KASPER, J. - Enteric bacterial toxins: mechanisms of action and linkage to intestinal secretion. Microbiol. Rev., 60: 167-215, 1996.

32. SERÉNY, B. - Experimental Shigella keratoconjunctivitis. A preliminary report. Acta microbiol. Acad. Sci. hung., 2: 293-296, 1955.

33. SVENNERHOLM, A.-M. \& WIKLUND, G. - Rapid GM1-enzyme-linked immunoabsorbent assay with visual reading for identification of Escherichia coli heat-labile enterotoxin. J. clin. Microbiol., 17: 595-600, 1983.

34. SVENNERHOLM, A.-M.; WIKSTRÖM, M.; LINDBLAD, M. \& HOLMGREN, J. Monoclonal antibodies against Escherichia coli heat-stable toxin (ST) and their use in a diagnostic ST ganglioside GM1 enzyme-immonoabsorbent assay. J. clin. Microbiol., 24: 585-590, 1986.

35. TARDELLI GOMES, T.A.; RASSI, V.; MACDONALD, K.I. et al. - Enteropathogens associated with acute diarrhoeal disease in urban infants in São Paulo, Brazil. J. infect. Dis., 164: 331-337, 1991.

36. THOREN, A. - The role of enteropathogenic Escherichia coli in infantile diarrhoea: aspects on bacteriology, epidemiology and therapy. Scand. J. infect. Dis., 37: 1-51, 1983. 
QUIROGA, M.; OVIEDO, P.; CHINEN, I.; PEGELS, E.; HUSULAK, E.; BINZTEIN, N.; RIVAS, M.; SCHIAVONI, L. \& VERGARA, M. - Asymptomatic infections by diarrheagenic Escherichia coli in children from Misiones, Argentina, during the first twenty months of their lives. Rev. Inst. Med. trop. S. Paulo, 42 (1): 9-15, 2000.

37. VERGARA, M.; QUIROGA, M.; GRENÓN, S. et al. - Identificación de enteropatógenos en la diarrea de la infancia en un estudio realizado en la ciudad de Posadas, Misiones, República Argentina. Rev. lat-amer. Microbiol., 34: 71-75, 1992.

38. VERGARA, M.; QUIROGA, M.; GRENÓN, S. et al. - Prospective study of enteropathogens in two communities of Misiones, Argentina. Rev. Inst. Med. trop S. Paulo., 38: 337-347, 1996.
39. VERGARA, M.; QUIROGA, M.; GRENÓN, S. \& PEGELS, E. - Enteropatógenos en la diarrea infantil de la ciudad de Posadas, Misiones. Infect. Microbiol. Clin., 5: 106112, 1993.

Received: 08 June 1999

Accepted: 11 November 1999 


\section{SUMMARY OF THESIS*}

NASCIMENTO, Maria Cláudia do - Estudo da prevalência de úlceras perianais em pacientes com AIDS e fatores associados. São Paulo, 1999. (Dissertação de Mestrado - Faculdade de Medicina da Universidade de São Paulo).

\section{PERIANAL ULCERATED LESIONS IN AIDS PATIENTS: PREVALENCE AND ASSOCIATED FACTORS}

Ulcerated perianal lesions are commonly observed in patients with AIDS, especially in advanced HIV disease. These lesions may continue to enlarge peripherally, causing pain and discomfort. Even though herpes simplex virus has been pointed out as the main etiologic agent, some other causes can be associated with perianal ulceration. There is a lack of information about risk factors associated with perianal ulcers in AIDS patients.

Mucocutaneous ulcers caused by herpes simplex virus are usually diagnosed by viral culture from a swab sample obtained from the lesion. Polymerase chain reaction has been used to diagnose genital herpetic ulcers and asymptomatic anogenital shedding detection of herpes simplex virus.
To estimate the association of ulcerated perianal ulcer with advanced HIV disease, 272 patients hospitalized at Instituto de Infectologia Emílio Ribas were included during 8 months. All of them were interviewed and had the perianal region examined in search of ulceration.

Perianal ulceration was found in $9.2 \%$ of patients. In multivariate analysis, the conditions significantly associated with the presence of perianal ulcer were: history of esophageal candidiasis and history of perianal ulcer. Herpes simplex virus was detected by polymerase chain reaction in $22 / 23(95.6 \%)$ and by viral culture in $12 / 23(52.2 \%)$ patients. 